\title{
Distribusi Land Surface Temperature (LST) Menggunakan Metode Spasial Berdasarkan Citra Landsat 8 di Kabupaten Manggarai Nusa Tenggara Timur Pada Periode Juni-Juli 2015-2019
}

\author{
Distribution Land Surface Temperature (LST) Using Spatial \\ Method Based on Landsat 8 Images in Manggarai, Nusa \\ Tenggara Timur in Periode of June-July 2015-2019
}

\author{
Lorensia Yatimas Murni $^{1}{ }^{*}$, I Made Yuliara ${ }^{1}$, Windaryoto ${ }^{1}$ \\ ${ }^{1}$ Program Studi Fisika, Fakultas Matematika dan Ilmu Pengetahuan Alam, Universitas Udayana, \\ Kampus Bukit Jimbaran, Badung, Bali, Indonesia (80361) \\ Email:*lorensyamurny@gmail.com; imdyuliara@unud.ac.id; windaryoto@unud.ac.id
}

\begin{abstract}
Abstrak - Pertumbuhan penduduk dan pembangunan yang pesat, mengakibatkan tersediaannya lahan kosong/terbuka yang bervegetasi berkurang, sehingga berpengaruh terhadap perubahan land surface temperature (LST). Land surface temperatur adalah temperatur pada permukan bumi yang merupakan hasil pantulan objek yang terekam oleh citra satelit pada waktu tertentu. Pada penelitian ini telah dilakukan pengolahan LST Kabupaten Manggarai NTT periode Juni-Juli 2015-2019, menggunakan metode spasial berdasarkan citra Landsat 8. Dari hasil pengolahan maka diperoleh distribusi LST, temperatur minimum dan maksimumnya. Distribusi LST tertinggi di Kabupaten Manggarai NTT tidak hanya terjadi di daerah pusat kota yakni Kecamatan Langke Rembong, tetapi juga terjadi di daerah pinggiran yaitu Timur Laut Kecamatan Reok dan Kecamatan Wae Ri'i. LST tertinggi di Kabupaten Manggarai NTT berada pada citra tanggal 7 Juli 2018 yang mencapai $42,312^{\circ} \mathrm{C}$ sedangkan LST terendah berada pada citra tanggal 4 Juli 2017 sebesar $-59,307^{\circ} \mathrm{C}$. Jika dilihat dari rata-rata LST yang diperoleh, maka rata-rata LST tertinggi berada pada citra tanggal 7 Juli 2018 dengan LST rata-rata sebesar 25,683 ${ }^{\circ} \mathrm{C}$ sedangkan LST dengan rata-rata terendah berada pada citra tanggal 4 Juli 2017 dengan rata-rata LST sebesar $5,218^{\circ} \mathrm{C}$.
\end{abstract}

Kata kunci: Pertumbuhan penduduk, Distribusi, Citra Landsat, land surface temperature, metode spasial, vegetasi.

\begin{abstract}
Population growth and rapid development have resulted in reduced availability of vacant/open vegetated land, thus affecting changes in land surface temperature (LST). Land surface temperature is the temperature on the earth's surface which is the result of the reflection of objects recorded by satellite images at a certain time. In this study, LST processing was carried out in Manggarai Regency, NTT for the period June July 2015-2019, using a spatial method based on Landsat 8 images. From the processing results, the LST distribution, minimum and maximum temperatures were obtained. The highest LST distribution in Manggarai Regency, NTT does not only occur in the downtown area, namely Langke Rembong District, but also occurs in suburban areas, namely the Northeast of Reok District and Wae Ri'i District. The highest LST in Manggarai Regency, NTT was on the image on July 72018 which reached $42,312^{\circ} \mathrm{C}$ while the lowest LST was on the image on July 4, 2017 of $-59,307^{\circ} \mathrm{C}$. When viewed from the average LST obtained, the highest average LST is in the image on July 72018 with an average LST of $25.683^{\circ} \mathrm{C}$ while the LST with the lowest average is in the image on July 4, 2017 with an average $L S T$ of $5,218^{\circ} \mathrm{C}$.
\end{abstract}

Key words: Population growth, Distribution, Landsat Imagery, land surface temperature, spatial method, vegetation.

\section{Pendahuluan}

Indonesia merupakan salah satu negara yang mengalami peningkatan populasi penduduk serta merupakan negara ketiga dengan populasi penduduk terbanyak di dunia [1]. Menurut Badan Pusat Statistik Indonesia (BPS), jumlah penduduk di Indonesia hingga September 2020 sebesar 270,2 juta jiwa. 
Kabupaten Manggarai adalah salah satu kabupaten yang cukup berkembang dan terdapat di Pulau Flores, Nusa Tenggara Timur. Kabupaten Manggarai menjadi salah satu kabupaten yang mengalami peningkatan penduduk. Berdasarkan laporan akhir dari rencana program investasi jangka menengah Kabupaten Manggarai, penduduk tetap di Kabupaten Manggarai tahun 2015 berjumlah 319.607 jiwa dan diperkirakan hingga tahun 2020 menjadi 342.908 jiwa, dengan rata-rata pertumbuhan 1,78\% per tahun. Adanya pertumbuhan penduduk dan pembangunan yang pesat, mengakibatkan tersediannya lahan kosong/terbuka yang bervegetasi akan berkurang, sehingga berpotensi memberikan pengaruh terhadap perubahan temperatur permukaan tanah atau land surface temperature (LST) di kota Manggarai [2].

Land surface temperature adalah temperatur pada permukan bumi yang merupakan hasil pantulan objek yang terekam oleh citra satelit pada waktu tertentu. Pengukuran LST dibutuhkan dalam berbagai studi, seperti studi iklim, hidrologi, ekologi dan biogeokimia. Peningkatan LST akan mempengaruhi cuaca dan pola iklim dunia [3].

Penelitian ini di harapkan dapat memperluas pengembangan ruang lingkup riset, sehingga pemanfaatan teknologi dapat dioptimalkan serta dapat dipakai sebagai rekomendasi kepada pengambil kebijakan untuk tetap menjaga temperatur sebagaimana sebelum terjadinya perubahan tutupan lahan/berkurangnya vegetasi. Hal ini dapat ditempuh dengan menambah ruang terbuka yang ditanami vegetasi sehingga perubahan temperatur yang terjadi dapat diatasi. Dalam pengolahan data citra satelit (Landsat 8), peneliti akan mempertimbangkan emisivitas vegetasi dan emisivitas tanah. Hasil yang diharapkan dari penelitian ini adalah diketahuinya distribusi temperatur permukaan tanah dan temperatur maksimum dan minimum di Kabupaten Manggarai NTT.

\section{Metode Penelitian}

Metode yang digunakan dalam penelitian ini adalah metode spasial. Analisis ini dilakukan untuk melakukan pengolahan citra Landsat 8 dengan tujuan menentukan distribusi LST, temperatur maksimum dan minimum. Penelitian ini mengambil daerah studi wilayah Kabupaten Manggarai NTT yang secara astronomis terletak pada $119,30^{\circ}-120,30^{\circ} \mathrm{BT}$ dan $8,30^{\circ}-8,00^{\circ} \mathrm{LS}$ seperti yang ditunjukkan pada Gambar 1.

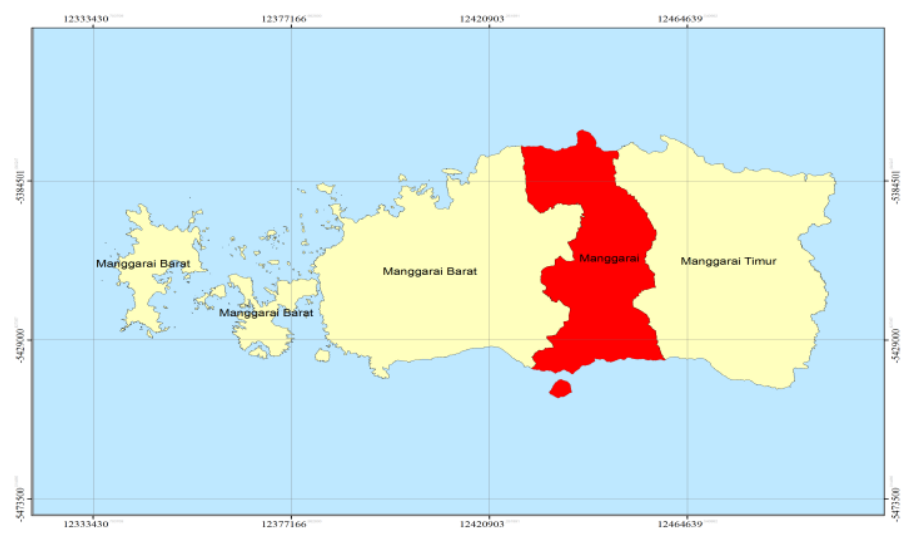

Gambar 1. Peta Lokasi Kabupaten Manggarai NTT.

Waktu penelitian dimulai sejak bulan Februari sampai bulan Juli 2021. Alat dan bahan yang digunakan adalah Software ArcGis, microsoft Office 2007, citra Landsat 8 dengan path/row 113/066 dan Peta administrasi wilayah Kabupaten Manggarai. Jenis data yang digunakan pada penelitian ini adalah data citra satelit Landsat 8 Level-1 Precision Terrain (L1TP). Data ini merupakan data spasial yang telah dikoreksi secara geometrik, diperoleh dengan cara mendownload dari laman https://earthexplorer.usgs.gov/. Tahapan dalam penelitian ini dibagi menjadi 3, yaitu:

a) Tahap Persiapan, berupa proses pengumpulan data dan pree-processing data. Data yang dikumpulkan adalah data citra satelit Landsat 8 tahun 2015 rekaman 13 Juni dan 15 Juli, 2016 rekaman 15 Juni dan 17 Juli, 2017 rekaman 2 Juni dan 4 Juli, 2018 rekaman 5 Juni dan 7 Juli, 2019 rekaman 8 Juni dan 10 Juli.

b) Tahap Pengolahan, berupa proses perhitungan land surface temperature.

- Cropping citra. Pemotongan citra dilakukan untuk mendapatkan daerah penelitian dengan tujuan untuk melakukan pengolahan data yang lebih fokus, terperinci dan teroptimal [4]. 
- Perhitungan normalized difference vegetation index (NDVI). Dalam perhitungan NDVI untuk menghitung tingkat kehijauan menggunakan band 4 dan band 5 dengan menggunakan persamaan sebagai berikut [5]:

$$
N D V I=\frac{R E D-N I R}{R E D+N I R}
$$

Dimana NIR adalah band near-infrared (band 5 pada Landsat 8) dan RED adalah band red (band 4 pada Landsat 8).

- Koreksi radiometrik. Koreksi ini diperlukan atas dasar dua alasan, yaitu untuk memperbaiki kualitas visual citra dan memperbaiki nilai-nilai piksel yang tidak sesuai dengan nilai pantulan atau pancaran spektral objek [6]. Untuk mengkonversi dari citra mentah atau digital number ke top of atmosphere (TOA) spectral radiance menggunakan radiance rescaling factors dalam file metadata Landsat 8 dengan menggunakan Persamaan (2) [7].

$$
L_{\lambda}=M_{L} Q_{c a l}+A_{L}
$$

Dimana $\mathrm{L}_{\lambda}$ adalah TOA spectral radiance (Watts $\left./ \mathrm{m}^{2} . \mathrm{srad} . \mu \mathrm{m}\right), \mathrm{Q}_{\mathrm{cal}}$ adalah nilai piksel citra satelit, $\mathrm{M}_{\mathrm{L}}$ adalah radiance_mult_band_x, dimana $\mathrm{x}$ adalah nomor band, dan $\mathrm{A}_{\mathrm{L}}$ adalah radiance_add_band_x, dimana $\mathrm{x}$ adalah nomor $b a n d$.

- Temperature brightness $(\mathrm{Tb})$. Dalam mengkonversi nilai spectral radiance ke temperature brightness digunakan persamaan berikut [8]:

$$
T_{b}=\frac{K_{2}}{\ln \left(\frac{K_{1}}{L_{\lambda}}+1\right)}
$$

Dimana $\mathrm{T}_{\mathrm{b}}$ adalah temperature brightness $(\mathrm{K}), \mathrm{K}_{1}$ adalah konstanta termal band 10 atau band 11 (ada di metadata), $\mathrm{K}_{2}$ adalah konstanta termal band 10 atau band 11 (ada di metadata) dan $\mathrm{L}_{\lambda}$ adalah spectral radiance pada band $\mathrm{ke}-\mathrm{i}\left(\mathrm{Wm}^{2}\right.$.sr. $\left.\mu \mathrm{m}\right)$.

- Perhitungan fractional vegetation cover (FVC). Nilai FVC berguna untuk mengetahui kerapatan vegetasi dan dapat diestimasi menggunakan nilai NDVI. Persamaan untuk menentukan nilai FVC adalah sebagai berikut [9]:

$$
F V C=\frac{N D V I-N D V I \text { soil }}{\text { NDVIveg }+ \text { NDVIsoil }}
$$

Dimana FVC adalah fraction vegetation cover, NDVI adalah nilai NDVI yang sebelumnya telah diperoleh, $\mathrm{NDVI}_{\text {soil }}$ adalah nilai NDVI untuk tanah= 0,2 dan $\mathrm{NDVI}_{\text {veg }}$ adalah nilai NDVI untuk vegetasi sama dengan nilai terbesar NDVI.

- Perhitungan Land Surface Emissivity (LSE). Perhitungan ini bertujuan untuk mengurangi kesalahan estimasi temperatur permukaan dan menggambarkan kemampuan objek, menggambarkan energi dengan menggunakan band 10 dan band 11. Ada pun persamaan untuk menentukan nilai LSE adalah sebagai berikut [9]:

$$
L S E=\varepsilon s \times(1-F V C)+\varepsilon v \times F V C
$$

Dimana LSE adalah land surface emissivity, FVC adalah nilai FVC yang sebelumnya diperoleh, $\varepsilon s$ adalah emisivitas tanah band 10 dan band 11, nilainya disajikan pada Tabel 1 dan $\varepsilon v$ adalah emisivitas vegetasi band 10 dan band 11, nilainya disajikan pada Tabel 1.

Tabel 1. Nilai emisisvitas TIRS band pada landsat 8 .

\begin{tabular}{crr}
\hline Emisivitas & Band 10 & Band 11 \\
\hline$\varepsilon \mathrm{S}$ & 0,971 & 0,977 \\
$\varepsilon \mathrm{V}$ & 0,987 & 0,989 \\
\hline
\end{tabular}

- Perhitungan Kombinasi LSE band 10 dan LSE band 11. Kombinasi LSE band 10 dan LSE band 11 menghasilkan dua nilai yaitu mean of LSE atau rata-rata LSE (m) dan difference of LSE atau selisih LSE $(\Delta \mathrm{m})$. Persamaan untuk menentukan nilai rata-rata LSE dan selisih LSE band 10 , band 11 adalah sebagai berikut [9]: 


$$
\begin{aligned}
& m=\frac{\varepsilon 10+\varepsilon 11}{2} \\
& \Delta m=\varepsilon 10-\varepsilon 11
\end{aligned}
$$

Dimana $\varepsilon_{10}$ adalah nilai LSE band 10 yang telah diperoleh sebelumnya, $\varepsilon 11$ adalah nilai LSE band 11 yang telah diperoleh sebelumnya, $\Delta \mathrm{m}$ adalah selisih nilai LSE band 10 dan band 11.

- Perhitungan land surface temperature (LST). Perhitungan LST menggunakan perhitungan yang dicetuskan oleh Sabrino pada tahun 1996 dan tahun 2008. Adapun persamaan tersebut adalah sebagai berikut (Rumengan, dkk, 2019) [9]:

$$
L S T=T_{b} 10+C 1\left(T_{b} 10-T_{b} 11\right)+C 2\left(T_{b} 10-T_{b} 11\right)^{2}+C 0+(C 3+C 4 W)(1-m)+(C 5+C 6 W) \Delta m
$$

Dimana LST adalah land surface temperature, C0...C6 adalah split window coefficient, nilainya disajikan pada Tabel 2, $\mathrm{T}_{\mathrm{b}} 10, \mathrm{~T}_{\mathrm{b}} 11$ adalah nilai $\mathrm{T}_{\mathrm{b}}(\mathrm{K})$ band 10 dan band 11 , $\mathrm{m}$ adalah rata-rata nilai LSE band 10 dan band $11, \mathrm{~W}$ adalah atmospheric water vapour content $=0,013$, dan $\Delta \mathrm{m}$ adalah selisih nilai LSE band 10 dan band 11.

Tabel 2. Split window coefficient.

\begin{tabular}{cc}
\hline Counstant & Value \\
\hline C0 & $-0,268$ \\
C1 & 1,378 \\
C2 & 0,183 \\
C3 & 54,300 \\
C4 & $-2,238$ \\
C5 & $-129,200$ \\
C6 & 16,400 \\
\hline
\end{tabular}

c) Tahap Akhir, berupa analisis penyebab perubahan LST di Kabupaten Manggarai NTT kemudian selanjutnya ditarik kesimpulan akhir.

\section{Hasil Dan Pembahasan}

a. Normalized difference vegetation index (NDVI)

Keberadaan vegetasi pada citra hasil transformasi NDVI di Kabupaten Manggarai NTT ditunjukkan dengan tingkat kerapatan vegetasi seperti pada Tabel 3, sedangkan untuk hasil citra NDVI ditunjukkan

\begin{tabular}{|c|c|c|}
\hline Warna & Nilai NDVI & Klasifikasi \\
\hline Kuning & $-1-0.1$ & Tidak bervegetasi seperti air dan awan \\
\hline Hijau & $0.1-0.2$ & $\begin{array}{l}\text { Vegetasi tidak rapat seperti lahan kosong, pemukiman, } \\
\text { bangunan dan industri }\end{array}$ \\
\hline Merah & $0.2-0.3$ & vegetasi cukup rapat seperti tegalan dan tumbuhan ternak \\
\hline Ungu & $0.3-0.4$ & $\begin{array}{l}\text { vegetasi rapat seperti perkebunan, sawah kering dan } \\
\text { semak belukar }\end{array}$ \\
\hline Biru & $0.4-0.6$ & vegetasi sangat rapat seperti hutan lebat \\
\hline
\end{tabular}
pada Gambar 2.

Tabel 3. Klasifikasi tingkat kerapatan vegetasi.

Dari Tabel 3 dapat diketahui bahwa wilayah yang tidak bervegetasi di Kabupaten Manggarai ditandai dengan warna kuning dengan besar nilai NDVI $-1-0.1$, wilayah yang vegetasi tidak rapat ditandai dengan warna hijau dengan besar nilai NDVI $0.1-0.2$, wilayah yang vegetasi cukup rapat ditandai dengan warna merah dengan besar nilai NDVI $0.2-0.3$, wilayah yang vegetasi rapat ditandai dengan warna ungu dengan besar nilai NDVI $0.3-0.4$ dan wilayah yang vegetasi sangat rapat ditandai dengan warna biru dengan besar nilai NDVI $0.4-0.6$. 


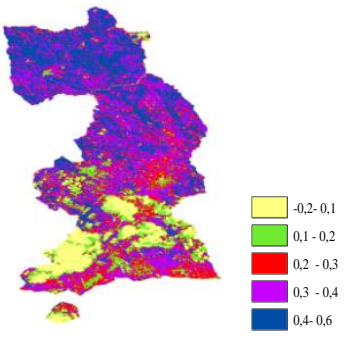

Tanggal 13 Juni 2015

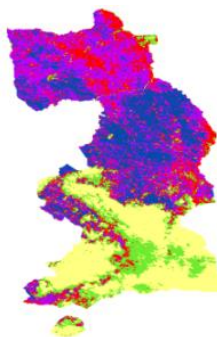

Tanggal 2 Juni 2017

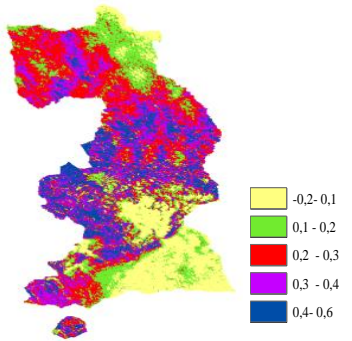

Tanggal 8 Juni 2019

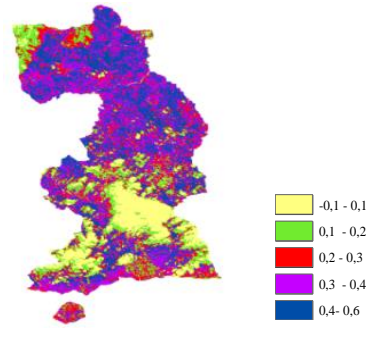

Tanggal 15 Juli 2015

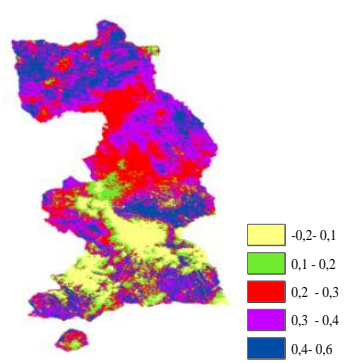

Tanggal 4 Juli 2017

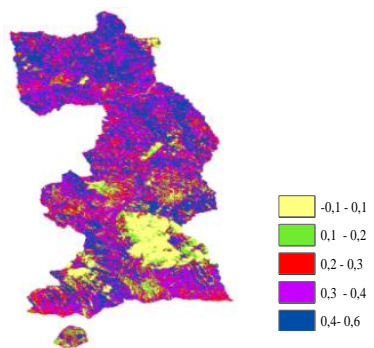

Tanggal 10 Juli 2019
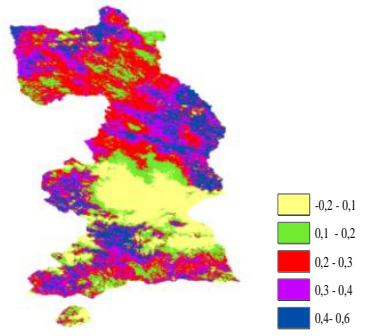

Tanggal 15 Juni 2016

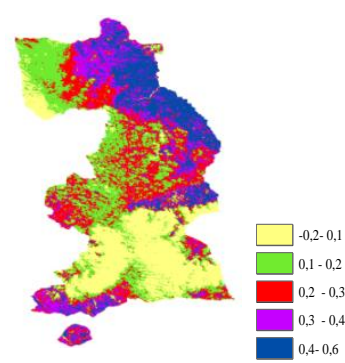

Tanggal 5 Juni 2018

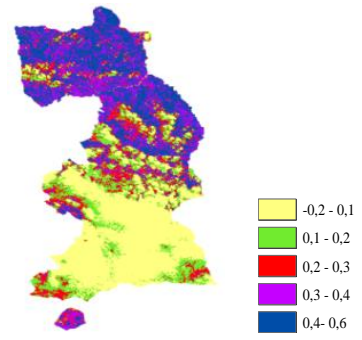

Tanggal 17 Juli 2016

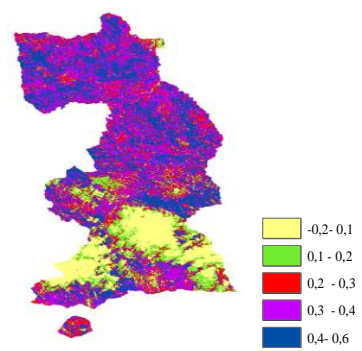

Tanggal 7 Juli 2018

Gambar 2. Hasil citra NDVI Kabupaten Manggarai periode Juni-Juli 2015-2019.

Berdasarkan hasil pengolahan data dari citra landsat 8, dapat diketahui bahwa tingkat kerapatan vegetasi di Kabupaten Manggarai berbeda. Pada Gambar 2 tanggal 13 Juni 2015 tingkat kerapatan vegetasi di Kabupaten Manggarai didominasi oleh vegetasi sangat rapat seperti hutan lebat. Gambar 2 tanggal 15 Juli 2015 tingkat kerapatan vegetasi di Kabupaten Manggarai didominasi oleh vegetasi rapat seperti perkebunan, sawah kering dan semak belukar. Gambar 2 tanggal 15 Juni 2016 tingkat kerapatan vegetasi di Kabupaten Manggarai didominasi oleh vegetasi cukup rapat seperti tegalan dan tumbuhan ternak. Gambar 2 tanggal 17 Juli 2016 tingkat kerapatan vegetasi di Kabupaten Manggarai didominasi oleh wilayah tidak bervegetasi seperti air dan awan. Gambar 2 tanggal 2 Juni 2017 tingkat kerapatan vegetasi di Kabupaten Manggarai didominasi oleh wilayah tidak bervegetasi seperti air dan awan. Gambar 2 tangggal 4 Juli 2017 tingkat kerapatan vegetasi di Kabupaten Manggarai didominasi oleh vegetasi cukup rapat seperti tegalan dan tumbuhan ternak. Gambar 2 tanggal 5 Juni 2018 tingkat kerapatan vegetasi di Kabupaten Manggarai didominasi oleh wilayah tidak bervegetasi seperti air dan awan. Gambar 2 tanggal 7 Juli 2018 tingkat kerapatan vegetasi di Kabupaten Manggarai didominasi oleh vegetasi sangat rapat seperti hutan lebat. Gambar 2 tanggal 8 Juni 2019 tingkat kerapatan vegetasi di Kabupaten Manggarai didominasi oleh vegetasi cukup rapat seperti tegalan dan tumbuhan ternak. Gambar 2 tanggal 10 Juli 2019 tingkat kerapatan vegetasi di Kabupaten Manggarai didominasi oleh vegetasi sangat rapat seperti hutan lebat. Perbedan tingkat kerapatan vegetasi ini merupakan salah satu faktor perubahan LST di Kabupaten Manggarai.

\section{b. Distribusi LST}

Distribusi LST sangat penting untuk diketahui pada suatu kabupaten, supaya dapat diketahui bahwa wilayah mana saja yang mengalami kenaikan LST dan dapat digunakan dalam proses perencanaan penggunaan dan pemanfaatan lahan. Nilai LST terendah pada hasil pengolahan ditandai dengan warna Ungu, dan LST tertinggi ditandai dengan warna Cokelat. Adapun hasil distribusi LST Kabupaten Manggarai ditunjukkan pada Gambar 3. 


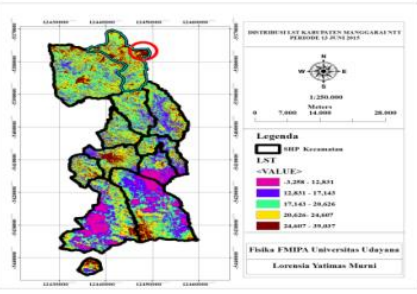

a)

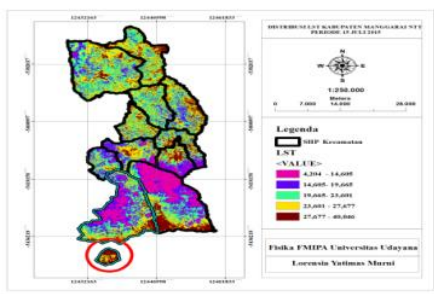

d)

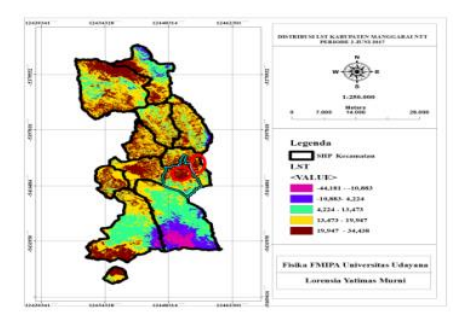

g)

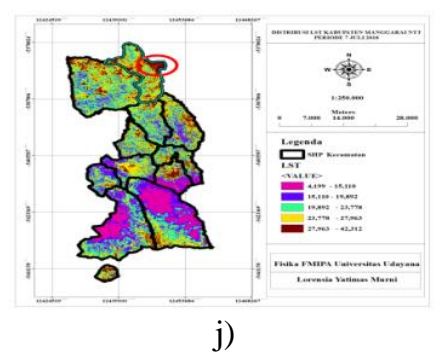

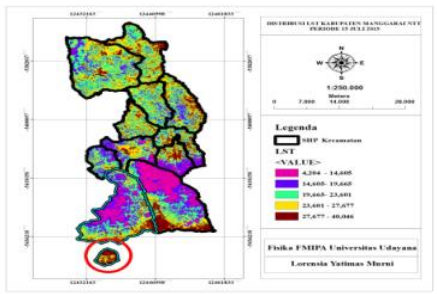

b)

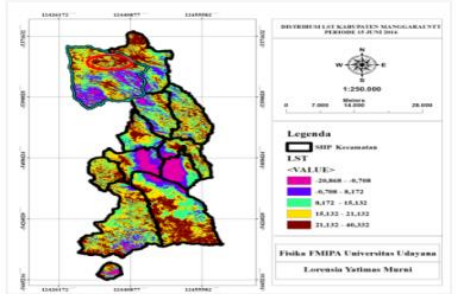

e)

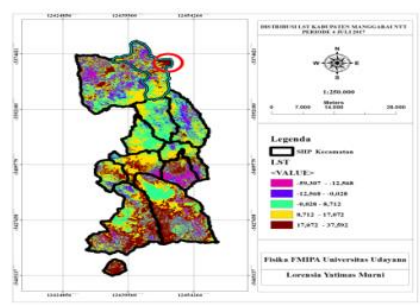

h)

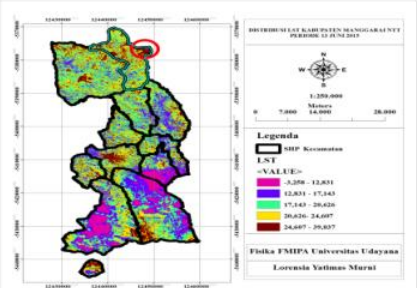

c)

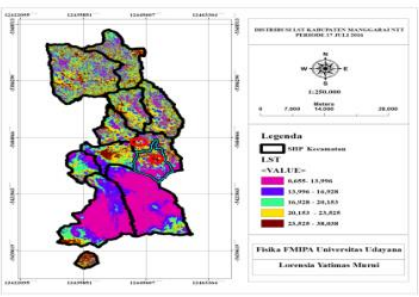

f)

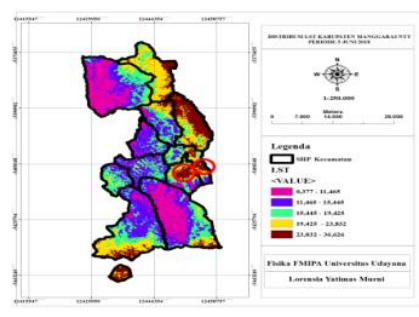

i)

Gambar 3. Distribusi LST Kabupaten Manggarai NTT periode Juni-Juli 2015-2019.

Pada Gambar 3a) tanggal 13 Juni 2015, distribusi LST di Kabupaten Manggarai NTT berkisar antara $-3,258-39,038^{\circ} \mathrm{C}$. Pada tanggal ini temperatur maksimumnya berada pada bagian Timur Laut Kecamatan Reok sedangkan temperatur minimumnya berada pada Kecamatan Satar Mese Barat. Pada Gambar 3b) tanggal 15 Juli 2015, distribusi LST di Kabupaten Manggarai NTT berkisar antara 4,204-40,046 ${ }^{\circ} \mathrm{C}$. Pada tanggal ini temperatur maksimum berada pada bagian Barat Daya Kecamatan Satar Mese Barat dan minimumnya berada pada Kecamatan Satar Mese Barat. Pada Gambar 3c) tanggal 15 Juni 2016, distribusi LST di Kabupaten Manggarai NTT berkisar antara -20,868-40,332 ${ }^{\circ} \mathrm{C}$. Pada tanggal ini temperatur maksimum berada pada bagian Timur Laut Kecamatan Reok Barat dan minimumnya berada pada Kecamatan Reok Barat. Pada Gambar 3d) tanggal 17 Juli 2016, distribusi LST di Kabupaten Manggarai NTT berkisar antara $0,655-38,038^{\circ} \mathrm{C}$. Pada tanggal ini temperatur maksimumnya berada pada bagian Timur Laut Kecamatan Langke Rembong dan bagian Barat Kecamatan Wae Ri'i, sedangkan temperatur minimumnya berada pada Kecamatan Reok Barat. Pada Gambar 3e) tanggal 2 Juni 2017, distribusi LST di Kabupaten Manggarai NTT berkisar antara $-44,181-34,438{ }^{\circ} \mathrm{C}$ dengan temperatur maksimumnya berada pada bagian Tenggara Kecamatan Wae Ri'i dan bagian Timur Laut Kecamatan Langke Rembong sedangkan temperatur minimumnya berada pada Kecamatan Satar Mese. Pada Gambar 3f) tanggal 4 Juli 2017, distribusi LST di Kabupaten Manggarai NTT berkisar antara -59,307-37,592 ${ }^{\circ} \mathrm{C}$. Pada tanggal ini temperatur maksimum berada pada bagian Timur Laut Kecamatan Reok dan temperatur minimumnya berada pada Kecamatan Reok. Pada Gambar 3g) tanggal 5 Juni 2018, distribusi LST di Kabupaten Manggarai NTT berkisar antara 0,377-36,626 ${ }^{\circ} \mathrm{C}$. Pada tanggal ini temperatur maksimumnya 
berada pada bagian Tenggara Kecamatan Wae Ri'i dan bagian Timur Laut Kecamatan Langke Rembong sedangkan temperatur minimumnya berada pada Kecamatan Reok Barat. Pada Gambar 3h) tanggal 7 Juli 2018, distribusi LST di Kabupaten Manggarai NTT berkisar antara 4,199-42,312 ${ }^{\circ} \mathrm{C}$. Pada tanggal ini temperatur maksimumnya berada pada bagian Timur Laut Kecamatan Reok sedangkan temperatur minimumnya berada pada Kecamatan Satar Mese Barat. Pada Gambar 3i) tanggal 8 Juni 2019, distribusi LST di Kabupaten Manggarai NTT berkisar antara 3,407-36,367 ${ }^{\circ} \mathrm{C}$. Pada tanggal ini temperatur maksimumnya berada pada bagian Tenggara Kecamatan Langke Rembong dan bagian Timur Laut Kecamatan Wae Ri'i sedangkan temperatur minimumnya tersebar di dua kecamatan yaitu Kecamatan Satar Mese dan Satar Mese Barat. Pada Gambar 3j) tanggal 10 Juli 2019, distribusi LST di Kabupaten Manggarai NTT berkisar antara 3,211-39,477 ${ }^{\circ} \mathrm{C}$. Pada tanggal ini temperatur maksimumnya berada pada bagian Timur Laut Kecamatan Reok sedangkan temperatur minimumnya berada pada Kecamatan Satar Mese. LST tertinggi di Kabupaten Manggarai NTT berada pada citra tanggal 7 Juli 2018 yang mencapai $42,312{ }^{\circ} \mathrm{C}$ sedangkan LST terendah berada pada citra tanggal 4 Juli 2017 sebesar $-59,307{ }^{\circ} \mathrm{C}$. Jika dilihat dari rata-rata LST yang diperoleh, maka rata-rata LST tertinggi berada pada citra tanggal 7 Juli 2018 dengan LST rata-rata sebesar $25,683{ }^{\circ} \mathrm{C}$ sedangkan LST dengan rata-rata terendah berada pada citra tanggal 4 Juli 2017 dengan rata-rata LST sebesar $5,218^{\circ} \mathrm{C}$.

Dari hasil pengolahan nilai LST terdapat perbedaan distribusi LST dari setiap citra yang digunakan. Hasil distribusi LST menunjukkan bahwa distribusi LST tertinggi di Kabupaten Manggarai NTT pada periode Juni-Juli 2015-2019 cenderung terjadi di beberapa wilayah yaitu Timur Laut Kecamatan Reok dan Kecamatan Wae Ri'i, serta bagian Tenggara Kecamatan Langke Rembong. Dari ketiga wilayah ini yang menjadi pusat kota Kabupaten Manggarai adalah Kecamatan Langke Rembong. Kecamatan Langke Rembong dikategorikan sebagai daerah perkotaan atau daerah urban sementara Kecamatan Reok dan Kecamatan Wae Ri'i merupakan daerah pinggiran atau non-urban.

Berdasarkan perbedaan distribusi LST tersebut, maka dapat diketahui bahwa distribusi LST di Kabupaten Manggarai NTT pada periode Juni-Juli 2015-2019 cenderung meningkat. Adapun grafik perubahan LST setiap kecamatan, Kabupaten Manggarai NTT periode Juni-Juli 2015-2019 ditunjukkan pada Gambar 4.

Berdasarkan grafik perubahan LST periode Juni-Juli 2015-2019 di Kabupaten Manggarai NTT, dapat diketahui bahwa setiap periode memiliki perbedaan temperatur maksimum dan minimum. Gambar 4a) periode Juni-Juli 2015 dimana pada setiap kecamatan, Kabupaten Manggarai NTT, temperatur maksimumnya mengalami peningkatan dan diikuti oleh temperatur minimum. Gambar 4b) periode JuniJuli 2016 terjadi peningkatan temperatur minimum di setiap kecamatan, Kabupaten Manggarai NTT sedangkan temperatur maksimum mengalami penurunan sehingga selisih temperatur maksimum dan minimumnya kecil. Gambar 4c) periode Juni-Juli 2017 terjadi peningkatan temperatur maksimum yang diikuti dengan penurunan temperatur minimum, dimana grafiknya saling menjauh sehingga memiliki selisih temperatur yang cukup besar pada setiap kecamatan, Kabupaten Manggarai NTT. Dari nilai temperatur maksimum dan minimum ini dapat dilihat bahwa grafiknya saling berbanding terbalik. Gambar 4d) periode Juni-Juli 2018 grafiknya cenderung linear, dimana temperatur maksimum mengalami peningkatan sedangkan temperatur minimum mengalami penurunan pada setiap kecamatan, Kabupaten Manggarai NTT. Gambar 4e) periode Juni-Juli 2019, pada setiap kecamatan, Kabupaten Manggarai NTT, temperatur maksimumnya mengalami peningkatan dan diikuti oleh temperatur minimum. Dari kelima grafik perubahan LST tersebut, terdapat salah satu grafik yang memiliki perubahan LST cukup memperihatinkan, yaitu grafik perubahan LST periode Juni-Juli 2017. Grafik perubahan LST tersebut dapat dilihat pada Gambar 4c). Pada Gambar 4c) ini perubahan temperatur minimumnya mencapai $-59,307{ }^{\circ} \mathrm{C}$. Dari nilai temperatur minimum ini, semestinya Kabupaten Manggarai menjadi salah satu wilayah yang tertutup es, tetapi faktanya berbanding terbalik, sehingga dapat disimpulkan bahwa terdapat faktor lain yang menyebabkan nilai temperatur ini mencapai $-59,307$ ${ }^{\circ} \mathrm{C}$. Faktor lain tersebut adalah keadaan data dan keberadaan awan yang menutupi wilayah pada periode ini berbeda dengan periode lainnya. Pada periode ini terdapat banyak tutupan awan serta keterbatasan citra bebas awan. Sehingga dapat disimpulkan bahwa perbedaan distribusi LST di Kabupaten Manggarai NTT, bukan hanya disebabkan oleh peningkatan jumlah/pertumbuhan penduduk dan berkurangnya lahan kosong/terbuka yang bervegetasi, seperti yang ditunjukkan pada Gambar 2, tetapi juga terdapat faktor lain yang menyebabkan perbedaan distribusi LST tersebut. Faktor lain yang memberikan perubahan terhadap LST tersebut adalah keadaan iklim/cuaca seperti radiasi surya, keawanan, hujan, suhu udara, angin dan kelembaban udara yang terjadi pada suatu wilayah. 


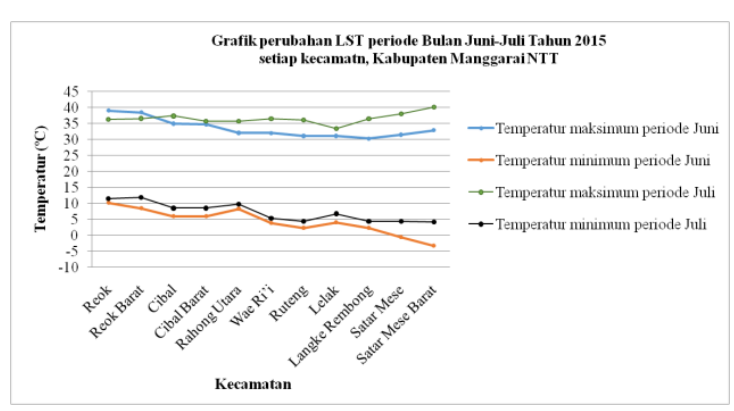

a)

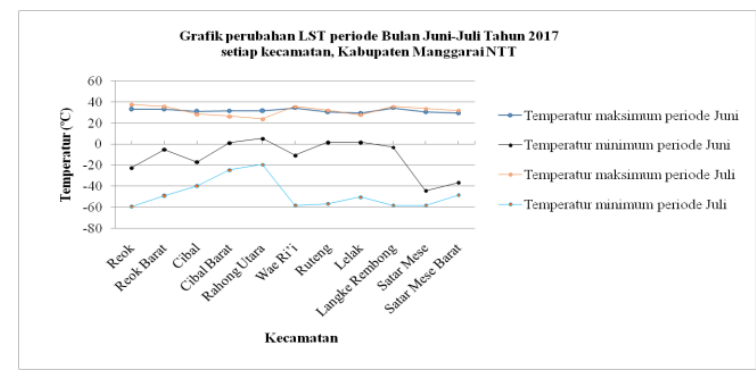

c)

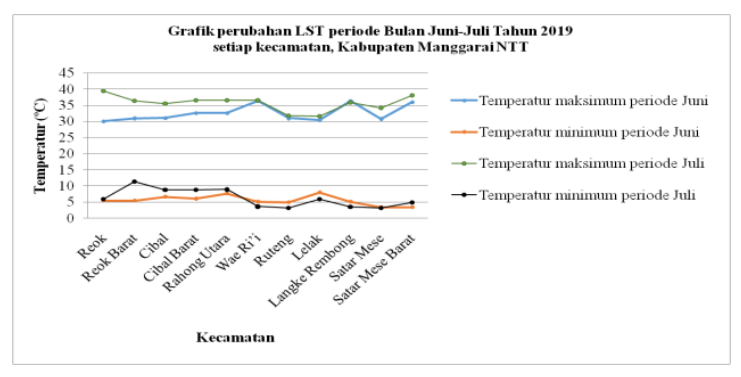

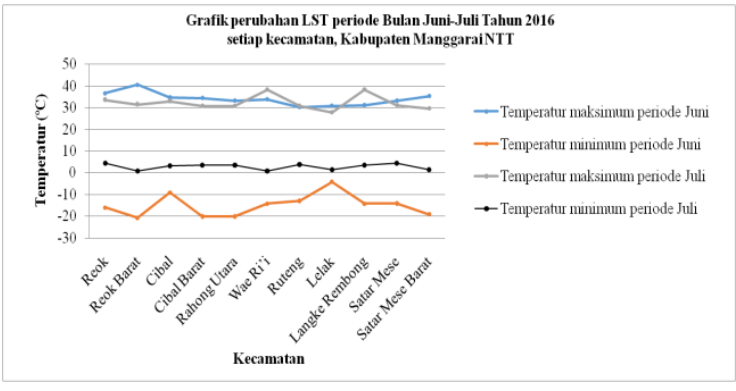

b)

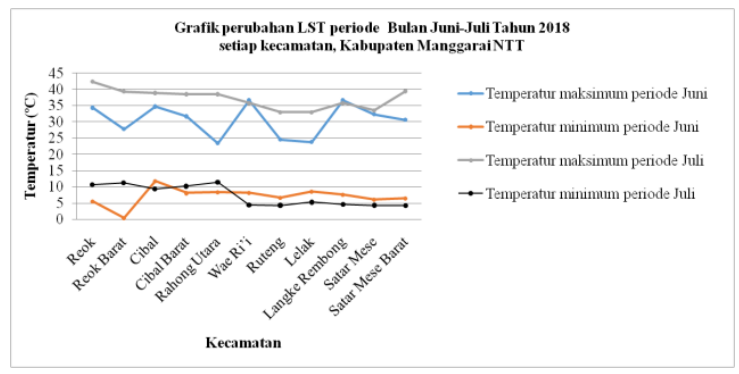

d)

e)

Gambar 4. Grafik perubahan LST periode Juni-Juli 2015-2019 di setiap kecamatan, Kabupaten Manggara NTT.

Secara umum distribusi LST tertinggi di Kabupaten Manggarai pada periode Juni-Juli 2015-2019 terjadi didaerah urban dan non urban, hal ini sesuai dengan penelitian yang telah dilakukan oleh Widya Ningrum dan Ida Narulita pada tahun 2018, yaitu Deteksi Perubahan Suhu Permukaan Menggunakan Data Satelit Landsat Multi-Waktu dengan studi kasus Cekungan Bandung. Pada penelitian ini menunjukkan bahwa di Cekungan Bandung telah terjadi perubahan distribusi suhu permukaan yang dicirikan oleh dua karakter hotspot yaitu daerah panas di daerah urban dan daerah panas di daerah nonurban. Daerah tersebut dicirikan menurunnya nilai indeks vegetasi, menurunnya nilai albedo atau ukuran reflektifitas permukaan dan meningkatnya nilai suhu permukaan tanah. Kecenderungan naik ini diduga sebagai akibat adanya perubahan tutupan lahan bervegetasi menjadi daerah yang lebih terbuka dan daerah terbangun [10].

\section{Kesimpulan}

Berdasarkan hasil penelitian yang telah dilakukan, maka dapat diambil kesimpulan sebagai berikut. Distribusi LST tertinggi di Kabupaten Manggarai NTT tidak hanya terjadi di daerah pusat kota yakni Kecamatan Langke Rembong, tetapi juga terjadi di daerah pinggiran yaitu Timur Laut Kecamatan Reok dan Kecamatan Wae Ri'i. LST tertinggi di Kabupaten Manggarai NTT berada pada citra tanggal 7 Juli 2018 yang mencapai $42,312^{\circ} \mathrm{C}$ sedangkan LST terendah berada pada citra tanggal 4 Juli 2017 sebesar $-59,307^{\circ} \mathrm{C}$. Jika dilihat dari rata-rata LST yang diperoleh, maka rata-rata LST tertinggi berada pada citra tanggal 7 Juli 2018 dengan LST rata-rata sebesar $25,683{ }^{\circ} \mathrm{C}$ sedangkan LST dengan rata-rata terendah berada pada citra tanggal 4 Juli 2017 dengan rata-rata LST sebesar $5,218{ }^{\circ} \mathrm{C}$. 


\section{Ucapan Terima Kasih}

Penulis menyampaikan terima kasih kepada Bapak dan Ibu dosen Fisika FMIPA Universitas Udayana yang telah membimbing, memberi saran dan masukan sampai terselesaikannya penelitian ini.

\section{Pustaka}

[1] M. N. Handayani, B. Sasmito dan A. Putra, Analisis Hubungan Antara Perubahan Suhu Dengan Indeks Kawasan Terbangun Menggunakan Citra Landsat (Studi Kasus: Kota Surakarta), Jurnal Geodesi Undip, vol. 6, no. 4, 2017, pp. 208-218.

[2] S. Irawan, J. Sirait, Perubahan Kerapatan Vegetasi Menggunakan Citra Landsat 8 di Kota Batam Berbasis Web, Jurnal Kelautan, vol. 10, no. 2, 2017, pp. 174-184.

[3] Sukristiyanti dan D. Marganingrum, Pendeteksian Kerapatan Vegetasi dan Suhu Permukaan Menggunakan Citra Landsat Studi Kasus: Jawa Barat Bagian Selatan dan Sekitarnya, Jurnal Riset Geologi dan Pertambangan, vol. 19, no. 1, 2009, pp. 15-24.

[4] J. S. Ati, Pemanfaatan Citra Landsat 8 SIG Untuk Identifikasi Kawasan Berpotensi Longsor, Skripsi, Jurusan Teknik Geodesi, Fakultas Teknik Sipil dan Perencanaan Institut Teknologi Nasional Malang, 2016.

[5] S. N. Lufilah, Pemanfaatan Citra Landsat 8 Untuk Analisis Indeks Vegetasi Di DKI Jakarta, Jurnal Lanskap Indonesia, vol. 9, no. 1, 2017, pp. 73-80.

[6] H. F. Baihaqi, Y. Prasetyo dan N. Bashit, Analisis Perkembangan Kawasan Industri Kendala Terhadap Perubahan Suhu Permukaan (Studi Kasus: Kawasan Industri Kendala, Kabupaten Kendala), Jurnal Geodesi Undip, vol. 9, no. 1, 2020, pp. 176-186.

[7] D. P. Wiguna, Identifikasi Suhu Permukaan Tanah Dengan Metode Konversi Digital Number Menggunakan Teknik Penginderaan Jauh Dan Sistem Informasi Geografi, Jurnal Teknologi Informasi dan Komunikasi, vol. 6, no. 2, 2017, pp. 59-69.

[8] R. Sari, W. Anurogo dan M. Z. Lubis, Pemetaan Sebaran Suhu Penggunaan Lahan Menggunakan Citra Landsat 8 Di Pulau Batam, Jurnal Integrasi, vol. 10, no. 1, 2018, pp. 32-39

[9] S. H. Rumengan, V. A. Kumuru dan I. L. Moniaga, Persebaran Suhu Permukaan dan Pemanfaatan Lahan di Kota Manado, Jurnal Spasial, vol. 6, no. 2, 2019, pp. 231-238.

[10] W. Ningrum dan I. Narulita, Deteksi Perubahan Suhu Perumukaan Menggunakan Data Satelit Landsat Multi-Waktu dengan studi kasus Cekungan Bandung, Jurnal Teknologi Lingkungan, vol. 19, no. 2, 2018, pp. 145-154. 